\title{
Botanical Composition of Steer Diets on Mes- quite and Mesquite-free Desert Grassland
}

\author{
H.D. GALT, BRENT THEURER, AND S. CLARK MARTIN
}

\begin{abstract}
Botanical composition of cattle diets on mesquite and mesquitefree desert rangeland was determined on a weight basis by a microscope point technique and density constants of species. Pastures consisted primarily of grasses, small amounts of forbs and shrubs, and velvet mesquite (17\% crown canopy) on one unit. Dietary composition of plant groups consisted of 67 to $97 \%$ grasses, 0 to $4 \%$ forbs, and trace to $33 \%$ shrubs. Species composition of diets varied by seasons and among animals. Plant preference was not necessarily related to plant availability. Composition of diets was markedly different from composition of pastures. Black grama averaged only $3 \%$ of diets, but comprised about one-third of herbage production. Arizona cottontop, which averaged $20 \%$ of herbage on pastures, was the most consistently selected species, averaging $34 \%$ of the diet. Seasonal preference was shown for certain grasses such as rothrock grama in spring and bush muhly in winter. Highest preference for shrub species was shown in winter and early summer. Overall dietary composition between pastures was much the same, but average herbage production for a 2-year period was $347 \mathrm{~kg} /$ ha greater where mesquite had been controlled. Leaves comprised the major plant part of steer diets on both pastures. Leaf content of diets increased from winter to summer while stems decreased for the same periods. Botanical composition of animal diets can be a guide to more efficient use of the range resource by grazing animals.
\end{abstract}

Proper management of our range resources is necessary to meet increasing demands for red meat. A better understanding of the botanical composition of the grazing animal's diet will help the resource manager make sound decisions regarding management of the range and care of the animal. More complete information on the diet of grazing animals is being obtained through the use of fistulated animals.

Several investigators have made botanical analyses of animal diets on a qualitative basis with fistulated cattle and sheep (Cook et al. 1958, Connor et al. 1963, and Edlefsen et al. 1960). Recent studies of botanical composition of the grazing animal's diet have been on a quantitative basis (Van Dyne and Heady 1965, Galt et al. 1969, Free et al. 1971, Thetford et al. 1971). These studies have shown that cattle and sheep graze selectively and species composition of the animal's diet varies with season of use (Theurer et al. 1976).

The objective of this study was to determine the quantitative botanical composition of steer diets on a desert grassland. Diets of cattle on mesquite infested and mesquite-free pastures were compared during four seasons of a year.

Authors are, respectively, range conservationist, Soil Conservation Service, U.S Dep. Agr., Bismarck, N.D. (formerly research associate, University of Arizona when research was conducted); professor, Department of Animal Sciences, and professor, Department of Range Management, University of Arizona, Tucson. Dr. Galt is currently assigned to Tunisia with the Agency for International Development (AID) with a participating agency agreement.

This article is Arizona Agr. Exp. Sta. Journal Article No. 3349. The study was supported in the past by U.S. Forest Service Grant and conducted in cooperation with Western Regional Research Project W-94, Range Livestock Nutrition.

Manuscript received August 15, 1980.

\section{Experimental Procedure}

The study area was on the Santa Rita Experimental Range about $56 \mathrm{~km}$ south of Tucson, Arizona. Two adjacent 16.2 ha pastures used for the study were similar in vegetation cover except for a $17 \%$ canopy cover of velvet mesquite (Prosopis juliflora var. velutina (Woot.) Sarg. on one unit (Fig. 1). Mesquite on the adjacent pasture had been individually treated with low grade diesel oil in 1954 and 1955. Percent kill of mesquite was about $100 \%$.

Grasses comprised most of the vegetation and were dominantly Arizona cottontop, black grama, slender grama, and spidergrass (see Table 1 for scientific names). Smaller amounts of shrubs occurred on both pastures. Common shrubs were catclaw, false mesquite, desert honeysuckle, and Englemann pricklypear. Forb species made up a minor part of the total vegetation.

Condition of the range in relation to site potential was classed as fair on the mesquite pasture and good on the mesquite-free pasture according to Forest Service surveys. Predominant soils of the area are White House gravelly sandy loam and Tumacacori coarse sandy loam (Young et al. 1935). Annual precipitation averages about $40.6 \mathrm{~cm}$ with $60 \%$ falling from late June through September. Generally, grass green-up begins during the March-April period
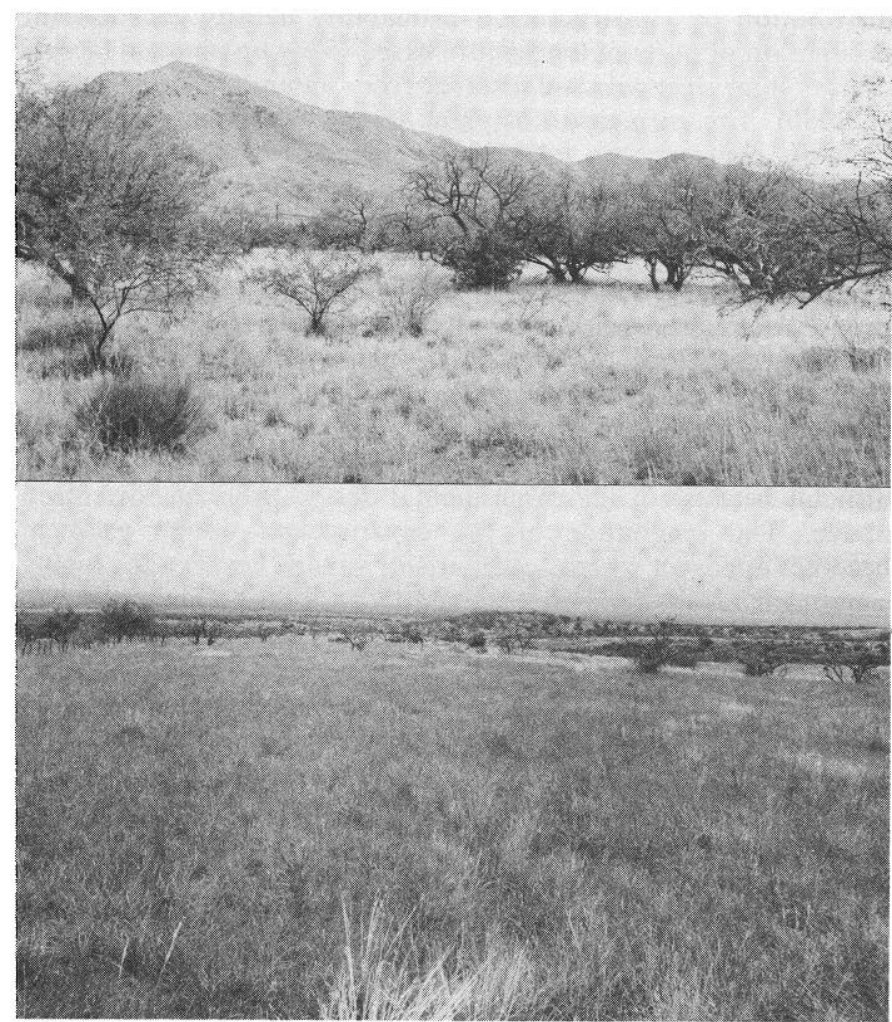

Fig. 1. Study area showing mesquite and mesquite-free desert grassland pastures on the Santa Rita Experimental Range. 
and May and June are usually without effective rainfall. Most herbaceous plant growth occurs in July and August but may continue into September and October if moisture is available. Precipitation was favorable for plant growth during the period of the study. Total rainfall in 1966 was $41.2 \mathrm{~cm}$ and $48.9 \mathrm{~cm}$ in 1967 . Rainfall totals in 1966 and 1967 during the period from June through September were 26.7 and $25.0 \mathrm{~cm}$, respectively.

Rumen fistulated steers (2-year old grade Herefords) were paired and placed on the experimental pastures from December 1966 to September 1967. Dietary samples were collected two consecutive days for two periods in each of the four seasons according to a cross-over experimental design. Seasons (and sampling periods) were as follows: winter (Jan. 22-23 and Feb. 5-6); spring (Apr. 16-17 and May 3-4); early (dry) summer (June 17-18 and July 5-6); and summer (Aug. 7-8 and Aug. 22-23). Pairs of steers were rotated between grazing units after each collection period. Forage intake and digestibility investigations were also made in conjunction with this study (Galt 1972).

Forage samples of steer diets were obtained by rumen evacuations (Lesperance et al. 1960). The cattle were penned at daybreak before starting to graze. The rumen and reticulum were cleared of ingesta and rinsed with water prior to sampling. Ingesta was temporarily stored in clean receptacles. Evacuated steers were allowed to graze for about 45 minutes. While the steers were grazing, one steer from each pair was observed with binoculars to determine as closely as possible the species grazed. Freshly grazed material was then removed from the rumen and the original rumen ingesta was replaced. Rumen forage samples were placed in plastic bags and quick-frozen with dry ice in the field. Samples that were collected from each steer for two consecutive days per sampling period were combined on an equal weight basis before botanical analyses. A total of 32 dietary samples were examined.

Botanical analyses of rumen forage samples were made in the laboratory using the microscope point technique as illustrated by Harker et al. (1964) and used by Galt et al. (1969). Botanical composition was determined on a weight basis through the use of density constants (wt./vol.) as described by Galt (1972). Plant part composition remained on a percent point basis.

Rumen forage samples were mixed in water using a rotating tumbler for 15 minutes and then spread on absorbent paper to air-dry. A rand om sample of masticated forage was taken to cover the bottom of a $45 \times 15 \mathrm{~cm}$ tray to approximately $3 \mathrm{~mm}$ in depth. Masticated plant material was examined with a binocular microscope having 20 to $80 \times$ magnification. Plant fragments were identified by a key based on morphological characteristics of plant parts in known specimens. Four hundred microscope points were taken per sample and recorded as hits on plant blade, sheath, leaf, stem, inflorescence or unidentifiable part. Percent points per sample was based on the total number of identifiable points. The unidentifiable portion of the sample was assumed to be proportional to the identifiable. Percent points of a species was found to be approximately equal to percent volume (Galt 1972). Density constants $(\mathrm{g} / \mathrm{cc})$ were developed for each species to convert percent points to percent weight. Percent weight of mesquite pods in samples collected from the cattle during the summer was determined by hand separation.

Botanical composition of the experimental pastures was determined on a weight basis at the end of the growing seasons in October of 1966 and 1967. Composition and production of herbage was measured by placing $50,0.89 \mathrm{~m}^{2}$ quadrats in each pasture using the double-sampling method (Wilson et al. 1944). Foliage above $1.5 \mathrm{~m}$ on shrubs was not sampled. Herbage in plots was clipped at ground level. Crown canopy of mesquite was determined by the line transect method. Utilization checks were made after the first four trials on both pastures and just before the summer grazing season in July. Utilization was determined as percent weight removed from the key plant species in each pasture using the grazed-plant-count method of Roach (1950).

Whole plant samples for eight major grass species observed grazed by the fistulated steers were collected for analyses of plant part composition. Approximately $100 \mathrm{~g}$ dry weight samples of species were randomly collected from each pasture on the rumen sample collection dates previously given. The species were separated into blade, sheath, stem, and inflorescence, and dried at $45^{\circ} \mathrm{C}$ for 24 hours.

Data were analyzed by analyses of variance based on a crossover experimental design (Cochran and Cox 1964). Duncan's mul-

Table 1. Botanical composition and herbage production of mesquite and mesquite-free pastures on the Santa Rita Experimental Range.'

\begin{tabular}{|c|c|c|c|c|}
\hline \multirow[b]{3}{*}{ Species } & \multicolumn{4}{|c|}{ Pasture } \\
\hline & \multicolumn{2}{|c|}{ Mesquite } & \multicolumn{2}{|c|}{ Mesquite-free } \\
\hline & $\%$ & $\mathrm{~kg} / \mathrm{ha}$ & $\%$ & $\mathrm{~kg} / \mathrm{ha}$ \\
\hline $\begin{array}{l}\text { GRASSES } \\
\text { Arizona cottontop } \\
\text { (Trichachne californica) }\end{array}$ & 27 & 220 & 12 & 139 \\
\hline $\begin{array}{l}\text { Black grama } \\
\text { (Bouteloua eriopoda) }\end{array}$ & 29 & 234 & 32 & 373 \\
\hline $\begin{array}{l}\text { Spidergrass } \\
\text { (Aristida ternipes) }\end{array}$ & 8 & 67 & 16 & 185 \\
\hline $\begin{array}{l}\text { Slender grama } \\
\text { (Bouteloua filiformis) }\end{array}$ & 7 & 56 & 13 & 146 \\
\hline $\begin{array}{l}\text { Rothrock grama } \\
\text { (Bouteloua rothrockii) }\end{array}$ & 6 & 47 & 8 & 93 \\
\hline $\begin{array}{l}\text { Sideoats grama } \\
\text { (Bouteloua curtipendula) }\end{array}$ & 7 & 57 & 4 & 45 \\
\hline $\begin{array}{l}\text { Plains bristlegrass } \\
\text { (Setaria macrostachya) }\end{array}$ & 5 & 38 & $\mathrm{~T}$ & 16 \\
\hline $\begin{array}{l}\text { Santa Rita threeawn } \\
\text { (Aristida glabrata) }\end{array}$ & 5 & 39 & 3 & 36 \\
\hline $\begin{array}{l}\text { Bush muhly } \\
\text { (Muhlenbergia porteri) }\end{array}$ & 4 & 34 & 5 & 45 \\
\hline $\begin{array}{l}\text { Tanglehead } \\
\text { (Heteropogon contortus) }\end{array}$ & 2 & 16 & 5 & 49 \\
\hline Other grasses ${ }^{2}$ & $\mathrm{~T}$ & $\mathrm{~T}$ & $\mathrm{~T}$ & $\mathrm{~T}$ \\
\hline $\begin{array}{l}\text { FORBS } \\
\text { Melon-loco } \\
\text { (Apodanthera undulata) }\end{array}$ & $\mathrm{T}$ & $\mathrm{T}$ & $\mathrm{T}$ & $\mathrm{T}$ \\
\hline $\begin{array}{l}\text { Tetramcrium } \\
\text { (Tetramerium hispidum) }\end{array}$ & $\mathrm{T}$ & $\mathrm{T}$ & $\mathbf{T}$ & $\mathbf{T}$ \\
\hline $\begin{array}{l}\text { Wright's buckwheat } \\
\text { (Eriogonum wrightii) }\end{array}$ & $\mathrm{T}$ & $\mathrm{T}$ & $\mathrm{T}$ & $\mathrm{T}$ \\
\hline $\begin{array}{l}\text { Careless weed } \\
\text { (Amaranthus palmeri) }\end{array}$ & $\mathrm{T}$ & $\mathbf{T}$ & $\mathrm{T}$ & $\mathrm{T}$ \\
\hline Other forbs ${ }^{3}$ & $\mathrm{~T}$ & $\mathrm{~T}$ & $\mathrm{~T}$ & $\mathrm{~T}$ \\
\hline $\begin{array}{l}\text { SHRUBS } \\
\text { Velvet mesquite } \\
\text { (Prosopis juliflora var. velutina) }\end{array}$ & $17^{4}$ & - & 0 & 0 \\
\hline $\begin{array}{l}\text { False mesquite } \\
\text { (Calliandra eriophylla) }\end{array}$ & $\mathrm{T}$ & 10 & 2 & 22 \\
\hline $\begin{array}{l}\text { Desert honeysuckle } \\
\text { (Anisacanthus thruberi) }\end{array}$ & $\mathrm{T}$ & $\mathrm{T}$ & $\mathrm{T}$ & $\mathrm{T}$ \\
\hline $\begin{array}{l}\text { Catclaw } \\
\text { (Acacia greggi) }\end{array}$ & $\mathrm{T}$ & $\mathrm{T}$ & $\mathrm{T}$ & 16 \\
\hline $\begin{array}{l}\text { Englemann prickly pear } \\
\text { (Opuntia englemannii) }\end{array}$ & $\mathrm{T}$ & $\mathrm{T}$ & $\mathrm{T}$ & $\mathrm{T}$ \\
\hline Other shrubs 5 & $\mathrm{~T}$ & $T$ & $\mathrm{~T}$ & $\mathrm{~T}$ \\
\hline Total & 100 & 818 & 100 & 1165 \\
\hline
\end{tabular}

'Values are averaged for 1966 and 1967, air dry weight basis. T-Refers to trace amounts less than $2 \%$.

Includes 9 other grass species.

Includes 4 other forb species.

4Percent crown cover of velvet mesquite.

IIncludes 4 other shrub species. 
tiple range test was used to test differences among sample means. Numbers of animals needed to sample certain botanical components for a specific degree of accuracy were calculated according to Snedecor (1956).

\section{Results and Discussion}

\section{Pasture Composition}

Species composition and herbage production of the experimental pastures averaged for 1966 and 1967 are shown in Table 1. Herbage production was consistently greater on the mesquite-free pasture. Production averaged 1165 and $818 \mathrm{~kg}$ per hectare for the mesquite-free and mesquite pastures, respectively for the two year period. Herbage production was greater in 1967 than in 1966 with an additional $337 \mathrm{~kg} /$ ha produced on the mesquite pasture and 673 $\mathrm{kg} / \mathrm{ha}$ on the mesquite-free pasture.

The pastures were managed for utilization to keep an adequate amount of the major grass species available. Greatest use occurred in early July, 1967, when the overall use of key species averaged $48 \%$ on the two pastures. During this period, $345 \mathrm{~kg} / \mathrm{ha}$ of herbage remained on the mesquite pasture and $422 \mathrm{~kg} / \mathrm{ha}$ of herbage was left on the mesquite-free pasture. Grass green-up began in early July and growth continued until October as a result of good moisture conditions. Thus, an adequate amount of forage was available throughout the study.

A total of 36 plant species were identified on the pastures. Grasses made up most of the herbage on the grazing units. Even though a wide variety of grasses were present on the experimental pastures (19 species), 10 species made up $98 \%$ of the total production. There were differences in amounts of major grasses between the two pastures. Arizona cottontop was more abundant on the mesquite pasture; spidergrass and slender grama were more prevalent on the mesquite-free pasture. The grama grasses, Bouteloua species, were an important group and comprised 49 to $58 \%$ of the total herbage production on the grazing units. Only minor amounts of forb species were found on the study area. Common forbs were melon-loco and Wright's buckwheat. In addition to mesquite on one unit, small amounts of shrub species such as false mesquite, desert honeysuckle, and catclaw were present on both pastures.

\section{Species Composition of Steer Diets}

Botanical composition of the steer diets are shown by pasture treatments within seasons (Table 2). A total of 27 plant species were identified in the rumen forage samples. Fifteen grass species made up 67 to $97 \%$ weight of the rumen forage samples; six of these species were found in trace amounts. Grasses have been reported to be the largest plant group of cattle diets on ranges by several workers (Cook et al. 1963, Van Dyne and Heady 1965, Thetford et al. 1971). The major grass in the diets was Arizona cottontop. Spidergrass and rothrock grama were the next most preferred species. Grasses such as plains bristlegrass, slender grama and sideoats grama were consistently selected to a lesser extent. Forbs were a minor component of the diet $(0-4 \%)$ and were selected primarily in winter and summer. Primary forbs in the diet were melon-loco, tetramerium and careless weed. Variable amounts of shrub species $(0-33 \%)$ were selected by the steers at different times of the year. Preference was shown for species such as velvet mesquite, false mesquite, catclaw, and Englemann prickly pear.

Coefficients of variation (CV) were calculated as a measure of variation for individual species and plant groups in the steer diets. Extreme variability was found for species and plant groups among the steer diets. Coefficients of variation ranged from 13 to $287 \%$. The CV's for Arizona cottontop, plains bristlegrass, and spidergrass were $91 \%, 93 \%$, and $57 \%$, respectively. The large variability in dietary botanical composition occurred among and within seasons.

The unidentifiable portion of the diet averaged $19 \%$ and ranged

Table 2. Botanical composition (\% weight) of steer diets by seasons on mesquite (M) and mesquite-free (MF) pastures of the Santa Rita Experimental Range. ${ }^{1,2}$

\begin{tabular}{|c|c|c|c|c|c|c|c|c|c|}
\hline \multirow[b]{2}{*}{ Species } & \multicolumn{2}{|c|}{ Winter } & \multicolumn{2}{|c|}{ Spring } & \multicolumn{2}{|c|}{ Early summer } & \multicolumn{2}{|c|}{ Summer } & \multirow{2}{*}{$\begin{array}{l}\text { Grand } \\
\text { mean }\end{array}$} \\
\hline & $\mathbf{M}$ & MF & $\mathbf{M}$ & $\overline{M F}$ & $\mathbf{M}$ & $\mathrm{MF}$ & $\mathbf{M}$ & MF & \\
\hline \multicolumn{10}{|l|}{ GRASSES } \\
\hline Arizona cottontop & 40 & 46 & 39 & 12 & 28 & 40 & 39 & 23 & 34 \\
\hline Plains bristlegrass & 12 & 4 & 6 & 3 & 10 & 7 & 10 & 7 & 7 \\
\hline Spidergrass & 2 & 9 & 13 & 19 & 12 & 21 & 20 & 14 & 15 \\
\hline Slender grama & 5 & 6 & 2 & 4 & 7 & 4 & 4 & 25 & 7 \\
\hline Sideoats grama & 2 & $T$ & 7 & 6 & 4 & 3 & 7 & 6 & 4 \\
\hline Rothrock grama & $T$ & $T$ & 17 & 37 & 6 & 15 & 4 & 16 & 12 \\
\hline Black grama & 4 & 4 & 5 & 7 & $\mathrm{~T}$ & $\mathrm{~T}$ & 0 & 3 & 3 \\
\hline Bush muhly & 9 & 18 & $\mathrm{~T}$ & 2 & $\mathrm{~T}$ & $\mathbf{T}$ & $\mathbf{T}$ & $\mathbf{T}$ & 4 \\
\hline Santa Rita threeawn & 2 & $\mathbf{T}$ & 5 & $\mathrm{~T}$ & $\mathrm{~T}$ & $\mathrm{~T}$ & 0 & $\mathbf{T}$ & $\mathrm{T}$ \\
\hline Other grasses ${ }^{3}$ & $T$ & $\mathbf{T}$ & 3 & $\mathrm{~T}$ & $\mathrm{~T}$ & $\mathrm{~T}$ & $\mathbf{T}$ & 2 & $\mathrm{~T}$ \\
\hline Total grasses & 76 & 87 & 97 & 90 & 67 & 90 & 84 & 96 & 86 \\
\hline \multicolumn{10}{|l|}{ FORBS } \\
\hline Melon-loco & $\mathrm{T}$ & 3 & 0 & $\mathbf{0}$ & $\mathbf{0}$ & $\mathrm{T}$ & $\mathrm{T}$ & $\mathrm{T}$ & $\mathrm{T}$ \\
\hline Tetramerium & 0 & 0 & $\mathbf{0}$ & $\mathbf{0}$ & $\mathbf{0}$ & 0 & $\mathbf{T}$ & 2 & $\mathbf{T}$ \\
\hline Carcless weed & 0 & 0 & 0 & $\mathbf{0}$ & 0 & 0 & $\mathbf{T}$ & 2 & $\mathbf{T}$ \\
\hline Other forbs ${ }^{4}$ & $\mathbf{T}$ & 0 & $\mathbf{0}$ & 0 & $\mathbf{0}$ & 0 & 0 & $\mathbf{T}$ & $\mathrm{T}$ \\
\hline Total forbs & $\mathbf{T}$ & 3 & 0 & 0 & 0 & $\mathrm{~T}$ & $\mathbf{T}$ & 4 & $\mathbf{T}$ \\
\hline \multicolumn{10}{|l|}{ SHRUBS } \\
\hline Velvet mesquite & 13 & 0 & 3 & $\mathbf{0}$ & 6 & 0 & 16 & $\mathbf{0}$ & 5 \\
\hline False mesquite & 9 & $\mathbf{T}$ & $\mathrm{T}$ & $\mathrm{T}$ & 27 & $\mathrm{~T}$ & 0 & $\mathbf{T}$ & 5 \\
\hline Catclaw & 0 & $\mathrm{~T}$ & 0 & 7 & 0 & 10 & 0 & $\mathrm{~T}$ & 2 \\
\hline Englemann prickly pear & 2 & 10 & $\mathbf{0}$ & 3 & $\mathrm{~T}$ & $\mathbf{T}$ & 0 & $\mathbf{T}$ & 2 \\
\hline Other shrubs 5 & 0 & 0 & $\mathbf{0}$ & $\mathrm{T}$ & $\mathbf{T}$ & $\mathbf{T}$ & $\mathrm{T}$ & $\mathbf{T}$ & $\mathrm{T}$ \\
\hline Total shrubs & 24 & 10 & 3 & 10 & 33 & 10 & 16 & $\dot{T}$ & 14 \\
\hline
\end{tabular}

Tabular values are averages of four steers. T-trace amounts less than $2 \%$ weight.

'Collection dates for seasons, 1967 are: Winter 1/22-23, 2/5-6; Spring 4/16-17, 5/3-4; Early Summer 6/17-18, 7/5-6; Summer 8/7-8, 8/22-23.

Includes six other grass species.

+Includes three other forb species.

'includes two other shrub species. 
from 8 to $25 \%$. The unidentifiable portion was highest in winter samples and became progressively less from spring to summer. Unidentifiable material consisted mainly of plant particles which could not be identified due to the absence of unique morphological characteristics of plant parts.

A second investigation was made simultaneously with this study on the behavior and grazing preference of fistulated steers on a desert grassland (Zemo 1968). Intensive observations were made of the fistulated steers used in this study from June 27 to September 9 , 1967. The grazing preference study was based on the number of bites taken by an animal, per unit of time. Zemo (1968) determined an overall preference rating of the major grasses, forbs and shrubs. His rating placed the following species in order of preference: Arizona cottontop, slender grama, plains bristlegrass, rothrock grama, spidergrass, sideoats grama, forbs, Santa Rita threeawn, bush muhly and shrubs. Except for the lower rating of spidergrass, Zemo's study approximates a preference rating based on amounts of these grasses in diets determined from this study. The behavior study of the same fistulated steers (Zemo 1968, Zemo and K lemmedson 1970) reported grazing times of $6.7 \mathrm{hr}$ per animal day and $2 \mathrm{hr}$ per animal night during four definite daylight and two nighttime periods throughout the study. These workers concluded that the activities of the fistulated steers did not differ from those of intact cattle.

\section{Seasonal Variation in Dietary Plant Species}

Arizona cottontop was the most consistently selected species throughout the year, comprising 12 to $46 \%$ of the diets, compared to 27 and $12 \%$ of the herbage production on the mesquite and mesquite-free pastures, respectively (Table 2 ).

Spidergrass, the second most abundant species in diets, was selected throughout the year. It was selected less in the winter $(6 \%$ avg.) than in other seasons ( $17 \%$ avg.). This bunchgrass produced an average of $13 \%$ herbage on the pastures. Plains bristlegrass was the third most consistently selected species by the steers. However, availability of this species on the study area was limited from 5 to less than $2 \%$ of herbage production. Slender grama was not grazed to a large degree until summer, when it accounted for $25 \%$ of the diets on the mesquite-free pasture.

Other grasses more preferred during certain seasons were rothrock grama and bush muhly. Rothrock grama was not grazed to any extent until spring when it was greater $(P<0.05)$ than in winter or summer diets. This species averaged $7 \%$ of herbage production, but comprised 17 and $37 \%$ of the spring diet. Bush muhly was greater $(P<0.05)$ in winter diets $(14 \%)$ than for other seasons (less than $2 \%$ ). This was a minor species on grazing units and comprised an average of $5 \%$ of the herbage production.

Black grama was a relatively minor component of the steer diets and was selected primarily in winter and spring. This species averaged $4 \%$ of diets in winter, $6 \%$ in spring and minor a mounts during summer periods, but made up about one-third of the total herbage production. Thus, black grama was not a preferred species in this study, confirming earlier reports (Campbell and Crafts 1939, Galt et al. 1969). Cattle diet studies on a semidesert range in New Mexico showed average preference for black grama by Hereford steers on year long and seasonally grazed range (Rosiere et al. 1975). However, plant composition of the New Mexico range was widely different from composition of the range in this study.

Common shrub species in the steer diets were false mesquite and catclaw. False mesquite was selected primarily in winter and early summer. On the mesquite-free pasture, catclaw was preferred in spring and early summer. These shrubs began growing in May and June and provided green forage when most grasses were dormant. Prickly pear cactus was selected primarily during winter. Moisture content of cactus may have been a factor affecting preference since this species maintains a high moisture level ( 70 to $80 \%$ avg.) during winter when the grasses are dormant and are low in moisture (10 to $20 \%$ avg.)

\section{Effects of Pasture on Steer Diets}

Overall dietary composition for the two pastures was much the same. Steers on the mesquite-free pasture consumed more $(P<0.05)$ slender grama and rothrock grama than on the mesquite infested pasture, but these species were also more abundant on the mesquite-free pasture. Total shrub species in diets were not significantly different between pasture treatments. False mesquite was preferred on the mesquite pasture while catclaw was selected from the mesquite-free pasture, although availability for these shrubs was similar between pastures. On the mesquite-infested pasture, mesquite leaves were most abundant in winter diets but more mesquite was consumed during summer as seedpods. New Mexico workers also noted consumption of mesquite during the summer, primarily as seedpods (Rosiere et al. 1975).

\section{Selectivity of Plant Parts}

Plant part composition of major species on the experimental pastures and in the cattle diets shows that the steers were selective not only of certain plants but also parts of species. Average plant part composition of eight major grass species as determined from whole, clipped plants on the experimental pastures is shown in Table 3. These species comprised a major part of the steer diets (Table 2). Availability of various grass parts varied by seasons. The percent of grass blades was highest in early summer and summer (47 to $30 \%$ ) compared to winter and spring (15 to $23 \%)$. Sheath parts remained at $24 \%$ weight except for a slight decline in early summer. More stems were available in winter and spring (51 to $44 \%)$ compared to both summer periods $(30 \%)$. Seedheads comprised $16 \%$ weight in summer but were less than $10 \%$ of plant weight in other seasons. Table 3. Plant parts ( $\%$ weight) of major grass species collected during four
seasons from experimental pastures.

\begin{tabular}{lcccc}
\hline \hline Grass parts & Winter & Spring & $\begin{array}{c}\text { Early } \\
\text { summer }\end{array}$ & Summer \\
\hline Blade & 15 & 23 & 47 & 30 \\
Sheath & 24 & 24 & 18 & 24 \\
Stem & 51 & 44 & 30 & 30 \\
Seedhead & 9 & 8 & 4 & 16
\end{tabular}

'Values are averages for eight grass species identified in diets (Arizona cottontop. plains bristlegrass, spidergrass, slender grama, black grama, sideoats grama. bush muhly, and rothrock grama)

2Dry matter basis.

Plant parts of all grasses in the cattle diets were averaged for pastures within season (Table 4) since no significant differences $(P<0.05)$ were found between mesquite and mesquite-free pastures. Plant part composition in diets was based on the number of microscope points. Considerably more grass blades were present in spring through summer diets $(\sim 60 \%)$ than in winter $(34 \%)$. Grass sheaths decreased from $34 \%$ in winter diets to a low of $14 \%$ in early summer. Grass stems comprised less than $20 \%$ of the diets and followed a decline similar to that for sheaths from winter $(19 \%)$ to summer $(3 \%)$. No particular preference was shown for grass seedheads, although the largest a mount $(8 \%)$ occurred in summer diets, when the predominant grasses were heading.

Only relative comparisons can be made between percentage by weight of parts of eight major grasses on the study area (Table 3 )

\section{Table 4. Parts of grasses ( $\%$ microscope points observed) in steer diets on desert grassland. ${ }^{1,2}$}

\begin{tabular}{lcccc}
\hline & \multicolumn{4}{c}{ Seasons } \\
\cline { 2 - 5 } Grass parts & Winter & Spring & $\begin{array}{c}\text { Early } \\
\text { summer }\end{array}$ & Summer \\
\hline Blades & 34 & 57 & 60 & 62 \\
Sheaths & 34 & 21 & 14 & 28 \\
Stems & 19 & 15 & 10 & 3 \\
Sccdheads & 2 & 3 & 2 & 8 \\
\hline
\end{tabular}

'Tabular values are averages of four steers.

${ }^{2}$ Grasses in the diet and collection dates for seasons are given in Table 2. 
and percent point composition of total grasses in diets (Table 4). Leaves (blade \& sheath) averaged $39,47,65$, and $54 \%$ weight in winter, spring, early summer, and summer respectively, for major grasses on the pastures. Leaf content of diets averaged $68,78,74$, and $90 \%$ points for the same periods. Steers were selecting leaves over stems in all seasons, and the increase of leaf content in steer diets appeared to be related to availability of leaf herbage as the growing season progressed.

Shrub leaves comprised a minor part of diets and was from trace to $7 \%$ based on number of microscope points. More stems of shrubs were in diets than leaves (up to $17 \%$; Galt 1972) with higher amounts in the early summer season as a result of false mesquite selectivity (Table 2 ).

\section{Number of Animals Required}

Estimates were made on the number of animals necessary to estimate certain botanical components of steer diets within $20 \%$ of the mean at the $90 \%$ confidence level. Number of animals required to sample range vegetation at this level of confidence would be excessive for components (Table 5). To sample major grasses and genus groups such as Arizona cottontop, spidergrass, rothrock grama, and Bouteloua species would required from 15 to 55 animals. To sample certain plant groups such as grasses or leaves would require fewer animals. Large variability among animals in selectivity for species in their diets was also supported by Van Dyne and Heady (1965). These workers determined that 24 or more animals were necessary to estimate major species by genus groups on annual California range within $10 \%$ of the mean and $90 \%$ confidence. These results suggest that it is impractical to measure major botanical genera with a high degree of confidence due to large variation of botanical composition among animals.

Table 5. Relative numbers of animals required to estimate certain botanical components of steer diets within $20 \%$ of the mean and $90 \%$ confidence.

\begin{tabular}{lc}
\hline \hline Botanical components & Number of animals \\
\hline Grasses & 55 \\
Arizona cottontop & 177 \\
Plains bristlegrass & 22 \\
Spidergrass & 9 \\
Slender grama & 54 \\
Sideoats grama & 33 \\
Rothrock grama & 15 \\
Bouteloua species & \\
Plant groups & \\
Grasses & 2 \\
Shrubs & 73 \\
Stems & 17 \\
Leaves & 2 \\
\hline
\end{tabular}

Results of this study support the work of other investigators (Connor et al. 1963, Van Dyne and Heady 1965, Bredon, et al. 1967) who found botanical composition to vary greatly among a nimals, season of use, and parts of species grazed. Species composition of animal diets in this study varied considerably among animals and seasons with a high degree of selectivity shown for certain species and plant parts. Composition of steer diet was quite different from the available herbage. This study shows that the presence of velvet mesquite had little effect on dietary composition, but a greater amount of forage was produced where mesquite was removed.

Based on results of this study, management plans for similar kinds of rangeland should provide for increase and maintenance of major species such as Arizona cottontop and spidergrass (Martin 1966). Not only are these grasses important to cattle diets, but they also include a significant part of the herbage on similar ranges in good to excellent condition.

Utilization may be improved for species such as black grama by grazing seasonally. Studies in southern New Mexico(Rosiere et al.
1975) showed that steers had a high preference for black grama in winter and in summer. Winter preference of black grama was attributed to its growth activity during this season while summer preference was related to lack of other forage during drought. A strong preference for black grama during December was shown in an earlier steer diet study on the Santa Rita Experimental Range (Galt et al. 1969).

\section{Summary and Conclusions}

Four rumen fistulated steers were used to study the botanical composition of cattle diets on mesquite and mesquite-free range during four seasons of a year. Grasses were the major plant group on the study area and forbs occurred in minor amounts on the pastures. Average density of mesquite on one pasture was $17 \%$ crown canopy and several shrub species occurred in small a mounts on both grazing units.

Species composition of steer diets varied by seasons and among animals. Certain species were preferred throughout the year, while others were selected on a seasonal basis. Composition of animal diets was markedly different from composition of the pastures. Grasses comprised 67 to $97 \%$ weight of the diets. Arizona cottontop was the most consistently selected species and was usually the largest component in the diets. This species made up 12 to $27 \%$ of the herbage on the grazing units. Black grama, in comparison, was only 0 to $7 \%$ of steer diets, but comprised about one-third of total herbage production. Spidergrass was the second most abundant species in diets. This species averaged 2 to $21 \%$ of diets and $13 \%$ of the herbage on the pastures.

Several other species were selected at certain seasons. Slender grama was not an important dietary component until summer when it comprised $25 \%$ of steer diets on the mesquite-free pasture. Rothrock grama was preferred in spring diets (up to $37 \%$ ), while bush muhly was selected primarily in winter. Slender grama and rothrock grama were the only two species that were different $(P<0.05)$ in diets between pastures. Overall species composition of diets were much the same between pastures. The presence of velvet mesquite had little effect on dietary composition, but more forage was produced where mesquite was removed $(1165 \mathrm{vs} 818 \mathrm{~kg} / \mathrm{ha}$ over a 2-year period).

Shrub species in diets varied with season (0 to 33\%). False mesquite was selected primarily in winter and early summer. Catclaw was preferred in spring and early summer. Mesquite leaves were consumed in small amounts during the year, but more preference was shown for mesquite seedpods in summer. Forbs were a minor dietary component ( 0 to $4 \%$ ) and were selected primarily in winter and summer.

The steers selected certain plant parts as well as species in their diet. Leaf content increased in diets from winter to summer while stems decreased for the same periods. Leaf content in steer diets appeared to be related to more available leaf herbage as the growing season progressed.

Such information on a mounts of species selected throughout the year by cattle should enable range managers to make more efficient use of forage resources on southwestern grass-shrub ranges.

\section{Literature Cited}

Bredon, R.M., D.T. Torell, and B. Marshall. 1967. Measurements of selective grazing of tropical pastures using esophageal fistulated steers. J. Range Manage. 20:317-320.

Campbell, R.S., and E.C. Crafts. 1939. How to keep and increase black grama on southwestern ranges. U.S. Dep. Agr. Leaflet 180. 8 p.

Cochran, W.G., and G.M. Cox. 1964. Experimental designs. John Wiley \& Sons, Inc., New York. 611 p.

Connor, J.M., V.R. Bohman, A.L. Lesperance, and F.E. Kinsinger. 1963. Nutritive evaluation of summer range forage with cattle. J. Animal Sci. 22:961-968.

Cook, C. Wayne, Joseph L. Thorne, Joseph T. Blake, and James Edlefsen. 1958. Use of an esophageal-fistula cannula for collecting forage samples by grazing sheep. J. Animal Sci. 17:189-193. 
Cook, C. Wayne, J.T. Blake, and J.W. Call. 1963. Use of esophagealfistulated cannulae for collecting forage samples from both sheep and cattle grazing in common. J. Anim. Sci. 22:579-581.

Edlefsen, James L., C. Wayne Cook, and Joseph T. Blake. 1960. Nutrient content of the diet as determined by hand-plucked and esophageal fistula samples. J. Anim. Sci. 19:560-567.

Free, James C., Phillip L. Sims, and Richard M. Hansen. 1971. Methods of estimating dry-weight composition in diets of steers. J. Anim. Sci. 32:1003-1007.

Galt, H.D., Brent Theurer, J.H. Ehrenreich, W.H. Hale, and S. Clark Martin. 1969. Botanical composition of diet of steers grazing a desert grassland range. J. Range Manage. 22:14-19.

Galt, H.D. 1972. Relationship of the botanical composition of steer diet to digestibility and forage intake on a desert grassland. Ph.D. Diss. University of Arizona, Tucson. $234 \mathrm{p}$.

Harker, K.W., D.T. Torell and G.M. Van Dyne. 1964. Botanical examination of forage from esophageal fistulas in cattle. J. Anim. Sci. 23:468-469.

Lesperance, A.L., V.R. Bohman, and D.W. Marble. 1960. Development of techniques for evaluating grazed forage. J. Dairy Sci. 43:682-689.

Martin, S. Clark. 1966. The Santa Rita experimental range. U.S. Forest Serv. Res. Pap. RM-22. 24 p.

Roach, Mack E. 1950. Estimating perennial grass utilization on semi-desert cattle ranges by percentage of ungrazed plants. J. Range Manage. 182185.
Rosiere, R.E., R.F. Beck, and J.D. Wallace. 1975. Cattle diets on semidesert grassland: botanical composition. J. Range Manage. 28:89-93.

Snedecor, G.W. 1956. Statistical methods (5th ed.). lowa State College Press, Ames. 534 p.

Thetford, F.0., R.D. Pieper, and A.B. Nelson. 1971. Botanical and chemical composition of cattle and sheep diets on pinyon-juniper grassland range. J. Range Manage. 24:425-430.

Theurer, C. Brent, A.L. Lesperance, and Joe D. Wallace. 1976. Botanical composition of the diet of livestock grazing native ranges. Pub. West. Reg. Coord. Committee No. 8, Agr. Exp. Sta. Tech. Bull. 233. Univ, Arizona, Tucson.

Van Dyne, George M. and H.F. Heady. 1965. Botanical composition of sheep and cattle diets on a mature annual range. Hilgardia. 36:465-492.

Wilm, H.G., D.F. Costello and G.E. Klipp. 1944. Estimating forage yield by the double-sampling method. Agron. J. 36:194-203.

Young, F.0., A.T. Sweet, A.T. Strahorn, T.W. Glassey, and E.N. Poulson. 1935. Soil Survey of the Tucson Area, Arizona. U.S. Dep. Agr. Pub. 19. Series 1931.

Zemo, Tesfay. 1968. Behavior and grazing preference of fistulated steers on a desert grassland. M.S. Thesis. Univ. Arizona, Tucson.

Zemo, Tesfay, and J.0. Klemmedson. 1970. Behavior of fistulated steers on a desert grassland. J. Range Manage. 23:158-162.

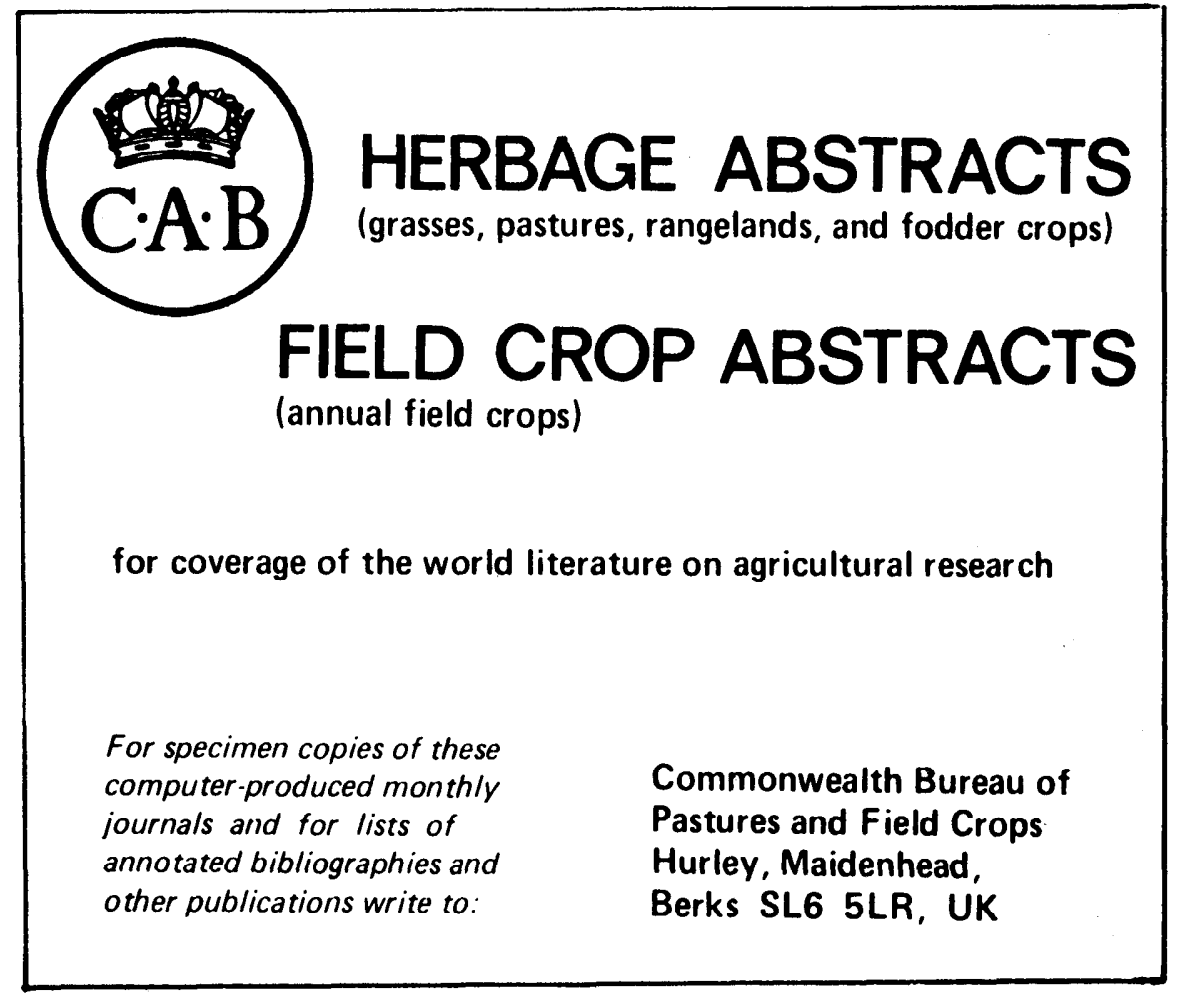

